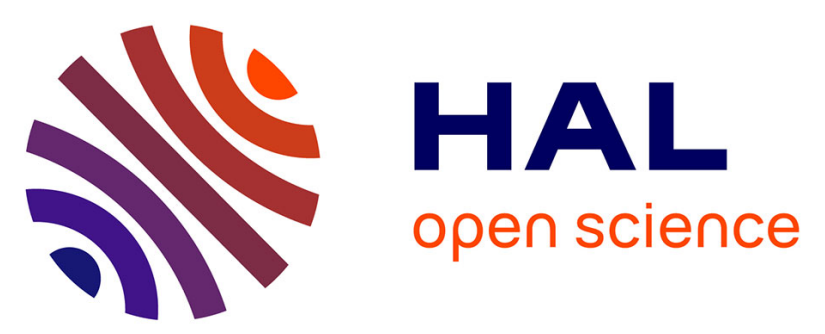

\title{
Introgression between introduced domesticated strains and mediterranean native populations of brown trout (Salmo trutta L.)
}

\author{
A. Barbat-Leterrier, René R. Guyomard, Francine Krieg
}

\section{- To cite this version:}

A. Barbat-Leterrier, René R. Guyomard, Francine Krieg. Introgression between introduced domesticated strains and mediterranean native populations of brown trout (Salmo trutta L.). Aquatic Living Resources, 1989, 2, pp.215-223. hal-02727746

\section{HAL Id: hal-02727746 \\ https://hal.inrae.fr/hal-02727746}

Submitted on 2 Jun 2020

HAL is a multi-disciplinary open access archive for the deposit and dissemination of scientific research documents, whether they are published or not. The documents may come from teaching and research institutions in France or abroad, or from public or private research centers.
L'archive ouverte pluridisciplinaire HAL, est destinée au dépôt et à la diffusion de documents scientifiques de niveau recherche, publiés ou non, émanant des établissements d'enseignement et de recherche français ou étrangers, des laboratoires publics ou privés. 


\title{
Introgression between introduced domesticated strains and mediterranean native populations of brown trout (Salmo trutta L.)
}

\author{
Anne Barbat-Leterrier ${ }^{(1)}$, René Guyomard and Francine Krieg \\ INRA, Laboraloire de Génétique des Poissons, 78350 Jouy-en-Josas, France. \\ (1) Present address: IJRA, Station de Ginétique quantitatize et appliqu\}e, $78_{350}$ Jouy'en-Josas, France.
}

Reccived $A$ pril 4, ig89; accepted Scptcmber 5, 1989 .

Abstract

Résumé

Barbat-Leterrier A., R. Guyomard, F. Krieg. Aquat. Liting Resour., 1989, 2, 215-223.

Keywords : Electrophoresis, Salmo trutta, Meditcranean population, restocking, introgression.

Introgression entre souches domestiques introduites et populations locales mediterranéennes de truite commune (Salmo trutta $L$.).

Introgression between introduced domesticated stocks and natural populations of brown trout was investigated by protein electrophoresis in three Mediterranean rivers. From each river, one undisturbed site and one, closcly located, yearly stocked site were sampled. Comparison of the elcctrophorctic variation observed in samples from the undisturbed sites with that in the introduced hatchery strains revealcd several specifically "domestic" variants. The genetic control of these variants was demonstrated by breeding experiments. The samples collected from the stocked sites showed introgression rates ranging from approximately 0 to $40 \%$. The genotype frequencies observed in these samples suggested that no reproductive barrier exists between introduced and native stocks and that they form random mating populations.

(1)

Une étude électrophorétique de la structure génétique de populations naturelles dans lesquelles sont régulièrement introduits des stocks de pisciculture a été entreprise dans trois rivières méditerranéennes. Sur chacune d'elles, un site non repeuplé et, à proximité de celui-ci, un site repeuplé chaque année ont été choisis. La comparaison des variations c̈lectrophorétiques observées dans les échantillons provenant des sites non repeuplés avec celles qui ont été trouvées dans les souches domestiques utilisées pour le repeuplement a permis de définir plusicurs allèles caractéristiques des souches domestiques. Le déterminisme génétique de ces variations électrophorétiques a été démontré par des croisements expérimentaux. Les échantillons prélevés dans les secteurs repeuplés révèlent des taux d'introgression variant de 0 à $40 \%$ environ. Les fréquences génotypiques observées suggèrent que les individus autochtones et introduits constituent une population panmictique hybride et qu'il n'existe aucun isolement reproducteur entre cux.

Mots-clés : Électrophorèse, Salmo trutta, populations méditerranéennes, repcuplement, introgression. 


\section{INTRODUCTION}

Hybridization is widespread in fish, especially in freshwater specics (Schwartz, 1972). Several characteristics of fish may explain their ability to hybridize: external fertilization, absence or weakness of ethological reproductive barriers and susceptibility to secondary contacts between recently evolved forms (Campton, 1987). Many salmonid taxa (species, subspecies...) may have differentiated recently during the quaternary era, when alternating glacial and warm periods considerably modified the geographic distribution of temperate species. In the present days, these forms may maintain their genetic integrity only when they inhabit separate hydrographic basins.

Human transfers of salmonid stocks into watersheds naturally inhabited by conspecific or congeneric populations have become frequent in recent decades. Such introductions offer the opportunity to analyse the extent and the nature of gene flow between differentiated populations.

In brown trout (Salmo trutta L.), a substantial amount of genetic divergence has accumulated between Mediterranean and Atlantic populations (Krieg and Guyomard, 1985). The degree of divergence between these two groups is comparable to that found between species or subspecies of NorthAmerican salmonids (Loudenslager and Gall, 1980; Smith, 1981; Stoneking et al., 1981). All domesticated brown trout stocks analysed clcarly originated from the Atlantic "subspecies" (Krieg and Guyomard, 1985). Thesc populations possess alleles which have never been found in virgin Mediterranean populations. The persistence of domesticated individuals among wild Mediterranean stock and their contribution to the natural reproduction can be easily detected with these diagnostic alleles.

In this paper, we report an electrophoretic analysis of populations sampled from sitcs which have been continuously stocked over more than ten years. Our results suggest that there is no reproductive barrier to genetic exchange between introduced domesticated and native Mediterrancan populations.

\section{MATERIAL AND METHODS}

\section{Matings for the gene segregation analysis}

Five full-sib matings were performed with different pairs of parents issued from hatchery strains (Guyomard and Krieg, 1983). In addition, a cross between a domesticated strain and a natural Breton strain (Elorn river) was performed. The allele frequencies observed in the Elorn population were described in Krieg and Guyomard (1985). Contrary to the hatchery strains, this population show's a high frequency of Ldh-5 (105); 10 males and 10 females of each origin were mated in this experiment. The four progenies from this cross and the five full-sib families were reared to 10 months and then analysed electrophoretically.

\section{Wild and hatchery samples for the study of stocking} effects

Three rivers were chosen in the Mediterranean area (fig. 1): the Coulomp (tributary of the Var), the Luech (tributary of the Ceze) and Maureillas (tributary of the Tech). In the upper watershed of each river, two sites were selected, 5 to $10 \mathrm{~km}$ apart, onc unstocked and the other stocked with introduced fish each year. The stocking effort for each site is given in table 1 . From the stocked site, age $0^{+}$and older fish (termed adults in the text) were collected. The two hatchery strains used for stocking the three sites were also analyzed (table 1).

\section{Elcctrophoretic methods}

Tissue extract preparation, electrophoretic techniques and staining procedures are described by Guyomard and Krieg (1983) and Krieg and Guyomard (1985). Nomenclature of loci and alleles follows the general recommendations proposed by Allendorf and Utter (1979).

Gene segregation statistics and principal component analysis

The symbols and statistics used for the gene segregation analyses are derived from Mather (1951) and detailed by May et al. (1979) and Taggart and Ferguson (1984). Conformity of observed genotypic distributions to Hardy-Weinberg expectations in wild and domesticated samples were tested by chi-square analysis. Gametic phase desequilibrium (D) between pairs of loci were estimated using the maximum likelihood method of Hill (1974) and tested against the null hypothesis, $\mathrm{D}=0$ (Hill, 1974).

Each sample was subjected to principal component analysis (PCA) using loci as characters. PCA was chosen because it permits us to treat the characters as quantitative variables. No more than two alleles per locus were found in all cases, except Fum- $(1,2)$, and three character states could be considered: $1,0.5$ and 0 for genotypes $100 / 100,100 / a$ and $a / a$ respectively ( 100 designating the common allele). For each river, the fishes from the wild sample and the hatchery strain were taken as informative individuals and those from the stocked site as supplemental individuals. Details on PCA are given by Lebart et al. (1985). 


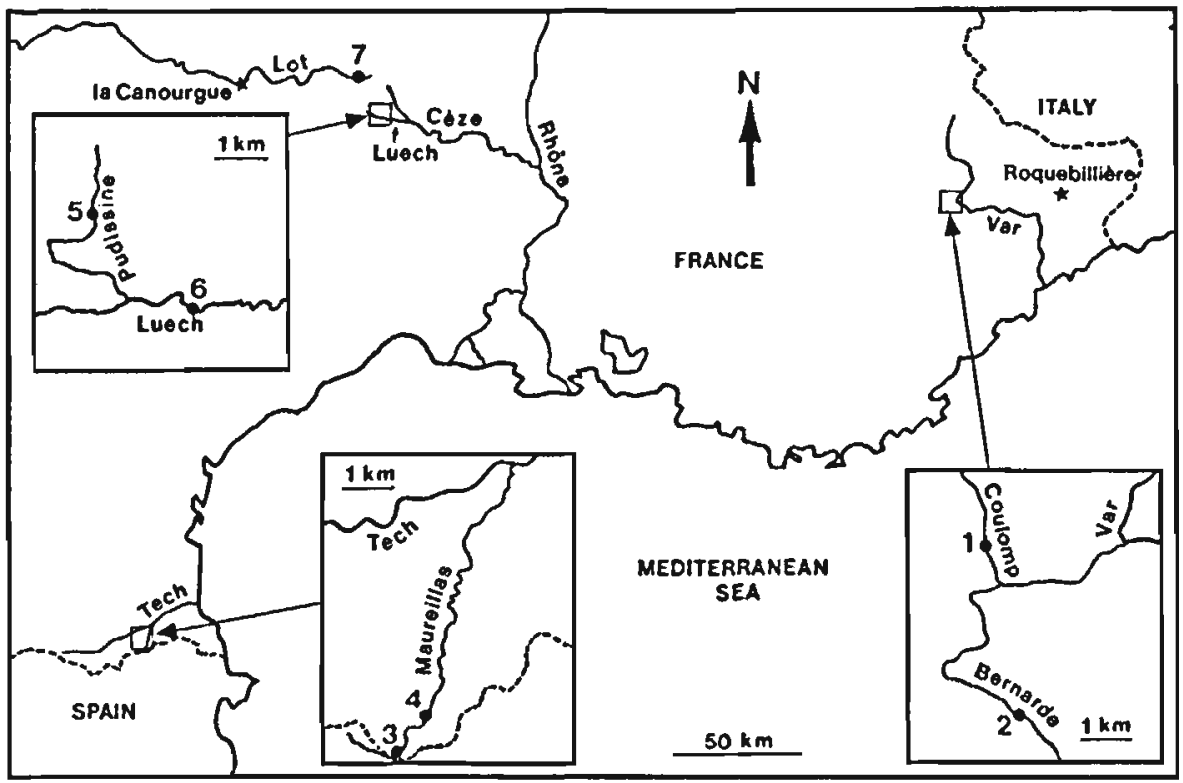

Figure 1. - Sampling locations for brown trout populations analysed. Sample numbers are the same as in table 1.

Table 1. - Location and main characteristics of the sample sites (sample numbers are the same as in figure 1).

\begin{tabular}{|c|c|c|c|c|}
\hline \multirow{2}{*}{ Site } & \multirow{2}{*}{$\begin{array}{c}\text { Stocking } \\
\text { (at yolk sac stage) }\end{array}$} & \multirow{2}{*}{$\begin{array}{l}\text { Hatchery } \\
\text { strain used }\end{array}$} & \multicolumn{2}{|c|}{ Sample size } \\
\hline & & & Adult $\left(1^{+} \leqq\right)$ & Fry $\left(0^{+}\right)$ \\
\hline & no & - & 20 & \\
\hline f & $\begin{array}{l}2,000 \mathrm{fry} / \mathrm{km} \text { for } \\
6 \text { years (April-May) }\end{array}$ & Roquebillière & 19 & 30 \\
\hline ) & no & - & 15 & \\
\hline & $\begin{array}{c}5,000 \text { fry } i \mathrm{~km} \text { for } \\
20 \text { years (February-March) }\end{array}$ & La Canourgue & 16 & 26 \\
\hline No. 3) & no & - & 17 & \\
\hline No. 4) & $\begin{array}{c}2,000 \mathrm{fry} / \mathrm{km} \text { for } \\
6 \text { years (February-March) }\end{array}$ & La Canourgue & 20 & 30 \\
\hline $\begin{array}{l}\text { chery strain) } \\
\text { (chery strain) }\end{array}$ & & & $\begin{array}{l}20 \\
20\end{array}$ & \\
\hline
\end{tabular}

\section{RESULTS}

\section{Gene segregation}

We analysed 37 single and 71 joint segregations in the five full-sib familics (table 2). Three single segregations deviated significantly from the expected mendelian proportions; these deviations were not consistently observed at a single locus and therefore probably occurred by chance. Two non-random joint segregations (between Mdh-2 and Mdh-3,4 and between Pmi-2 and Sdh-1) were also observed. No double heterozygous genotypes were observed at the isoloci (duplicated loci which have not diverged), Aat$(1,2), \mathrm{Cpk}-(1,2)$, and $\mathrm{Mdh}-(3,4)$ and therefore the existence of tetrasomic inheritance at these loci could not be tested. Gene segregation at Ldh-5 was analysed in the cross between the Breton stock and the hat- chery strain; no signilicant deviation from the expected proportions was detected (table 3).

Electrophoretic variation in domesticated and wild sanples

Products of 47 loci were examined in the domesticated strains and wild samples collected from the undisturbed sites and 17 of them were polymorphic (table 4). Allcle frequencics at isoloci could not be determined directly from the observed genotypes. We assumed that both Fum-1 and 2 were variable because they have several common alleles in some populations (Krieg and Guyomard, 1985; Guyomard, unpublished data). In contrast, variations observed at other isoloci (Aat-1 and 2, Cpk 1 and 2, Mdh-3 and 4) werc consistent with the assumption that one of the isoloci 
Table 2. - Single (along the diagonal) and joint (off the diagonal) segregations. Each individual block includes the number of families (left) and the number of individuals analysed per progeny (right). $p<0.05$.

MALE

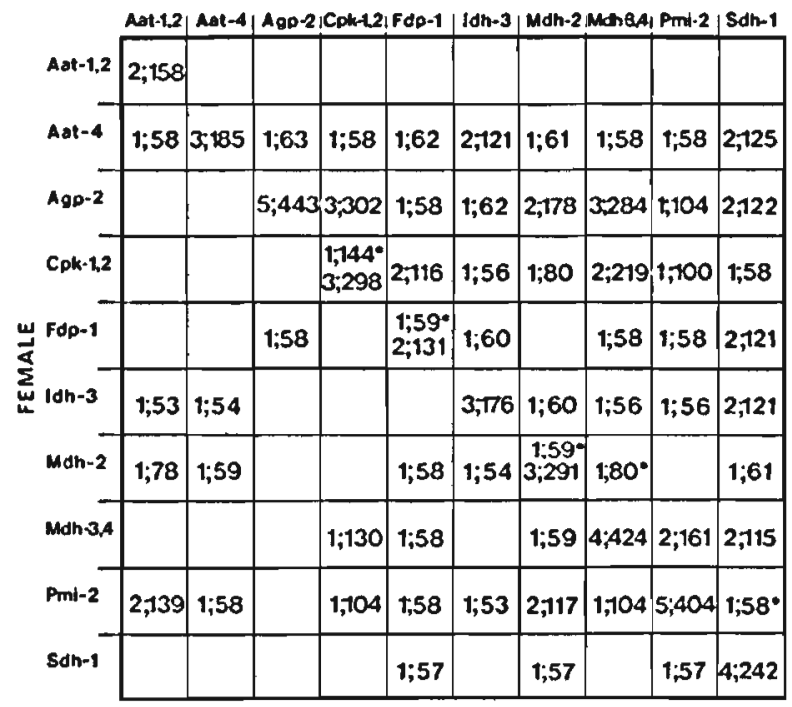

at Fum-(1,2), Fdp-1, Mdh-2, Pgi-2, Pmi-2 and Tfn. This sample also came from a native population which has not hybridized with a domesticated stock. The position of individuals along the first two principal component axes illustrates these conclusions well (fig. 2). Within each of these smaples, no departure from Hardy-Weinberg expectations and gametic phase descquilibrium between pairs of loci was observed.

\section{Analysis of samples collected in socked sites}

Only the most discriminating loci between hatchery and wild samples were analysed in samples from stocked areas (table 5). Allele frequency changes due to survival of hatchery fish and hybridization should affect all the loci at which significant allele frequency differences exist between hatchery and wild stocks. Morcover, because stocking and hybridization would be recent events, these changes should be proportional to the allele frequency differences between the hatchery strain and the native population. Defining $f n$, $f r$ and $f d$ as the allele frequencies in the native, stocked and domesticated samples respectively, and $r$ as the proportion of domesticated genes in a sample, then, $r=(f r-f n) /(f d-f n)$. We expect $r$ not to differ substantially from one locus to another. This seemed to

Table 3. - Gene segregation at Ldh-5 in the four groups from a cross between a hatchery strain and a natural Breton population. N: number of parents used; $n$ : number of offspring analysed.

\begin{tabular}{|c|c|c|c|}
\hline \multicolumn{4}{|c|}{ Loth-5 (105) frequencies observed in parents } \\
\hline $\begin{array}{l}\text { q Elorn } \\
(\mathrm{N}=10)\end{array}$ & $\begin{array}{l}\text { of Elorn } \\
(\mathrm{N}=9)\end{array}$ & $\begin{array}{l}\text { q Hatchery } \\
(\mathrm{N}=10)\end{array}$ & $\begin{array}{l}\text { of Hatchery } \\
(\mathbf{N}=10)\end{array}$ \\
\hline 0.70 & 0.63 & 0.05 & 0.00 \\
\hline \multicolumn{4}{|c|}{ Ldh-5 (105) frequencies observed in progenies } \\
\hline $\begin{array}{c}\text { 9 Elorn } \times 3 \text { Elorn } \\
(n=50) \\
067[0.66]\end{array}$ & $\begin{array}{c}\text { olorn } \times 0 \text { o Hatch. } \\
(n=50) \\
0.37\end{array}$ & $\begin{array}{c}\text { Q Ilatch. } \times 0^{n} \text { Elorn } \\
(n=50)\end{array}$ & $\begin{array}{c}\text { \& Hatch. } \times a^{n} \text { Hatch. } \\
(n=50) \\
0050005\end{array}$ \\
\hline 0.67 & $0.37[0.35]$ & $0.41[0.34]$ & $0.05[0.025]$ \\
\hline
\end{tabular}

[ ] : Expected frequencies assuming equal contribution of each parent. Chi-squares were not significant in the four cases.

was fixed; then, all variation was assigned to Aat1, Cpk-1 and Mdh-3. The hatchery samples were genetically very similar and differed significantly only at Pmi-2. The Coulomp and upper Maureillas samples, which are $350 \mathrm{~km}$ apart, had significant allele frequency differences at two loci (Me-2 and Cpk-3) only, but exhibited substantial genetic differentiation from the domesticated stocks. 12 alleles found at appreciable frequencics $(>0.10)$ in the hatchery

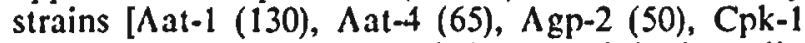
(125), Fdp-1 (100), Fum-1,2 (130) and (140), Ldh5(100), Mdh-2(200), Mdh-3 (75), Pmi-2 (105) and Tfn (100)] were not observed in Coulomp and upper Maureillas. These findings indicate that these two populations have not hybridized historically with domesticated stocks. The Pudissine sample was clearly differentiated from the two hatchery stocks at seven loci (Aat-4, Cpk-1, Fdp-1, Ldh-5, Mdh-2, Mdh3 and Pgi-2) and from the two other native samples be the case for age $0^{+}$fish and adult samples collected in lower Maurcillas and Bernarde sites, except at Pmi-2 (table 5). These samples were genetically more variable than the corresponding native populations. This is clcarly shown by the principal component analyses ( fig. $3 a, b, c)$. The two lower Maureillas polygons clearly overlapped the domesticated and upper Maureillas spaces. In contrast, the adult Bernarde space only slightly extends towards the domesticated strain while the age $0^{+}$fish sample coincides with the hatchery polygon. The abnormal values observed at Pmi-2 in the Bernarde sample (table 5) could result from sampling errors, allele frequency variations over generations in the hatchery strain, or natural occurrence of Pmi-2 (105) in the Bernarde population.

Significant deviations from Hardy-Weinberg expectations and gametic phase desequilibrium (table 6) between pairs of loci also support our conclusions of 
Table 4. - Allele frequencies in the samples analysed in this study.

\begin{tabular}{|c|c|c|c|c|c|c|c|c|c|c|c|c|}
\hline \multirow{2}{*}{ Locus } & \multirow{2}{*}{ Allele } & \multirow{2}{*}{ Coul. } & \multicolumn{2}{|c|}{ Bernarde } & \multirow{2}{*}{ Pud. } & \multicolumn{2}{|c|}{ Luech } & \multirow{2}{*}{ U. Mau. } & \multicolumn{2}{|c|}{$\begin{array}{c}\text { Lower } \\
\text { Maureillas }\end{array}$} & \multirow{2}{*}{ Roq. } & \multirow{2}{*}{ Can } \\
\hline & & & Fry & Adults & & Fry & Adults & & Fry & Adults & & \\
\hline & 130 & 0.00 & & & 0.00 & & & 0.00 & & & 0.05 & 0.17 \\
\hline \multirow[t]{2}{*}{ Aat 4} & 100 & 1.00 & & & 1.00 & & & 1.00 & & & 0.70 & 0.69 \\
\hline & 65 & 0.00 & & & 0.00 & & & 0.00 & & & 0.30 & 0.31 \\
\hline \multirow[t]{2}{*}{ Cpk-1 } & 100 & 1.00 & 0.55 & 0.95 & 0.97 & 1.00 & 1.00 & 1.00 & 0.93 & 0.83 & 0.42 & 0.70 \\
\hline & 125 & 0.00 & 0.45 & 0.05 & 0.03 & 0.00 & 0.00 & 0.00 & 0.07 & 0.17 & 0.58 & 0.30 \\
\hline \multirow[t]{2}{*}{ Cpk-3 } & 100 & 0.00 & 0.97 & 0.16 & 1.00 & 1.00 & 1.00 & 0.76 & & & 1.00 & 1.00 \\
\hline & 90 & 1.00 & 0.03 & 0.84 & 0.00 & 0.00 & 0.00 & 0.24 & & & 0.00 & 0.00 \\
\hline \multirow{2}{*}{ Fdp-1 } & 100 & 0.00 & 0.70 & 0.13 & 1.00 & 0.80 & 0.75 & 0.00 & 0.17 & & 0.78 & 0.60 \\
\hline & 150 & 1.00 & 0.30 & 0.87 & 0.00 & 0.20 & 0.25 & 1.00 & 0.83 & & 0.22 & 0.40 \\
\hline Ldh-5 & 105 & 1.00 & 0.03 & 0.84 & 1.00 & 0.65 & 0.72 & 1.00 & 0.65 & 0.38 & 0.00 & 0.00 \\
\hline \multirow[t]{2}{*}{ Mdh-2 } & 100 & 1.00 & & & 0.00 & 0.50 & 0.72 & 1.00 & & & 0.83 & 0.75 \\
\hline & 200 & 0.00 & & & 1.00 & 0.50 & 0.28 & 0.00 & & & 0.17 & 0.25 \\
\hline \multirow[t]{2}{*}{ Mdh-3 } & 100 & 1.00 & & & 1.00 & 1.00 & 1.00 & 1.00 & & & 0.85 & 0.68 \\
\hline & 75 & 0.00 & & & 0.00 & 0.00 & 0.00 & 0.00 & & & 0.15 & 0.32 \\
\hline \multirow[t]{2}{*}{$\mathrm{Me}-2$} & 100 & 0.37 & & & 1.00 & & & 1.00 & & & 1.00 & 1,00 \\
\hline & 90 & 0.63 & & & 0.00 & & & 0.00 & & & 0.00 & 0.00 \\
\hline \multirow[t]{2}{*}{ Pgi-2 } & 100 & 1.00 & & & 0.07 & 0.08 & 0.00 & 1.00 & & & 1.00 & 0.97 \\
\hline & 200 & 0.00 & & & 0.93 & 0.92 & 1.00 & 0.00 & & & 0.00 & 0.03 \\
\hline \multirow[t]{2}{*}{ Pgi-3 } & 100 & 1.00 & & & 1.00 & & & 1.00 & & & 0.90 & 0.95 \\
\hline & 105 & 0.00 & & & 0.00 & & & 0.00 & & & 0.10 & 0.05 \\
\hline \multirow[t]{2}{*}{ Pmi-2 } & 100 & 1.00 & 0.53 & 0.87 & 0.13 & & & 1.00 & 0.83 & 0.82 & 0.78 & 0.35 \\
\hline & 105 & 0.00 & 0.47 & 0.13 & 0.87 & & & 0.00 & 0.17 & 0.18 & 0.22 & 0.65 \\
\hline
\end{tabular}

Coul.: Coulomp; Pud.: Rudissine; U. Mau.: Upper Maureillas; Roq.: Roquebillière; Can: La Canourgue. *: both Fum-1 and 2 were assumed to be polymorphic with the same allele frequencies. Monomorphic loci are: $\Lambda$ at-1, $\Lambda \mathrm{dh}, \mathrm{Ak}, \mathrm{Cpk}-2$ and 4, Est-1, 2 and $5, \mathrm{Fdp}-2, \mathrm{Idh}-1,2,3$ and 4, Ldh-1, 2, 3 and 4, Mdh-1 and 4, Me-1, 3 and 4, P-alb-1 and 2, 6 pgdh, Pgi-1, Pgm-2, Sdh-2, Sod-1 and 2.

significant survival and reproduction of hatchery fish in Bernarde and Maureillas sites. Bernarde adults appear to be a mixture of native, hatchery and hybridized individuals, while fry appcar to be mainly hatchery fish except for one apparently native individual (fig. $3 a$ ). Thus, fry have a higher frequency of hatchery genes (table 5). Lower Maureillas adults and fry also appear to be composed of native, hatchery and hybridized individuals ( $f$ ig. $3 b$ and $c$ ). Adults in this case have a higher frequency of hatchery alleles (table 5).

A contrasting situation is observed in the Luech sample. First, the principal component analysis showed that the two Luech samples, which did not significantly differ, are not intermediate between the Canourgue strain and Pudissine sample ( $f i g .3 d$ ). Instead, the Luech population appeared to be intermediate between Pudissine and a population inhabiting the upper watershed of the lot (fig. 1 and $3 d$ ). Ifatchery strains were always found fixed or nearly fixed for Pgi-2 (100) and Ldh-5 (100) and to possess Fum-1,2 (140) in appreciable frequency (Kricg and Guyomard, 1985). The null or low frequencies of these alleles in the Luech sample suggest that stocking has generally failed at this sitc. Thus, the variations observed at Fdp-1, Ldh-5 and Mdh-2 in the Luech samples probably reflect natural polymorphism.

\section{DISCUSSION}

The genetic basis of the electrophoretic polymorphisms at all the diagnostic loci except Transferrin observed in this study has been verified with inheritance studies (Guyomard, 1986). No inheritance data were available for $T f n$, but the genetic interpretation of the variations found at this locus led to allele frequencies which were consistent with those observed at the other loci in hybridized populations. Taggart 


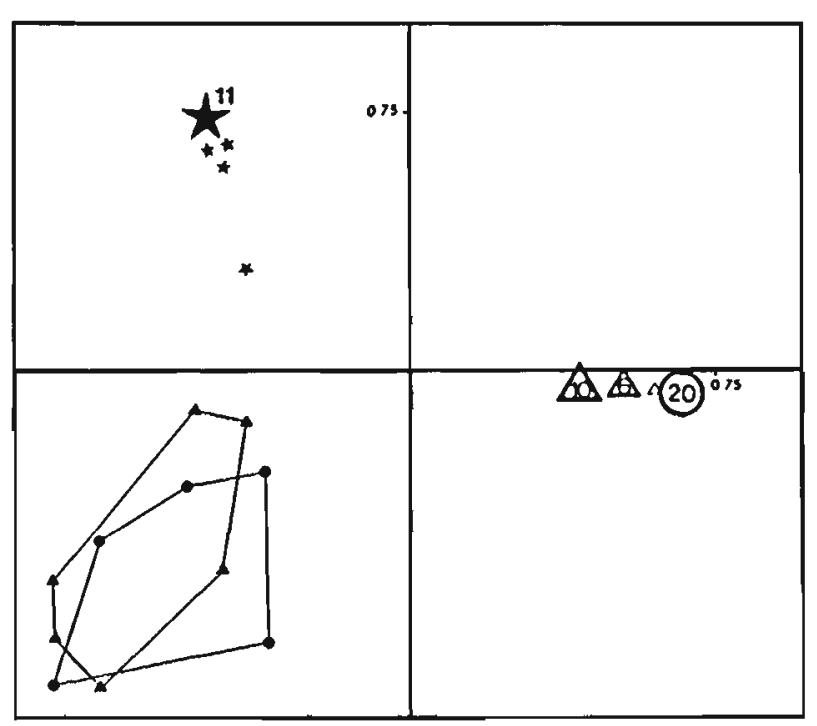

Figure 2. - Principal component analysis of hatchery strains and wild samples from unstocked sites: diagram of the projection on the two first axes plane (abscissa axis = first principal axis; ordinate axis $=$ second principal axis). $\Delta=\mathrm{La}$ Canourgue; $=$ Roquebillière; $O=$ Coulomp; $\Delta=$ Upper Maureillas; $*=$ Pudissine. The position of all wild individuals is shown and when several are projected on the same point their number is indicated. For the hatchery samples, only the smallest convex polygon bounding the sample space is shown.
(1984). For similar reasons, these data are not inconsistent. Additional segregation studies are required to determine if these two loci, as well as Pmi-2 and Sdh1 , are linked.

The Maureillas and Coulomp populations are genetically similar to the native Corsican populations (Guyomard and Krieg, 1986), being fixed for Ldh-5 (105) and Tfn (98) and lacking several alleles which are frequent in Atlantic and domesticated stocks (Krieg and Guyomard, 1985). This suggests that a genetic entity, subtantially differentiated from the Atlantic group (including the hatchery strains), inhabits the Mediterranean drainages. The standard genetic distance (Nei, 1975) between these two groups averages 0.10 . This value lies within the range of genetic distances found between salmonid subspecies (Loudenslager and Gall, 1980; Smith, 1981; Stoneking et al., 1981; Leary et al., 1987). In contrast, the Pudissine and Luech samples are genetically more similar to the Atlantic populations. Additional electrophoretic studies are required to determine the geographic range of the Mediterranean subspecies more accurately.

Evidence of natural introgression between domesticated and native brown trout was detected in the Bernarde and lower Maureillas samples. Age $0^{+}$fish from the lower Maureillas site appeared to constitute individuals sampled from a randomly mating population. This finding suggests that the genetic divergence between the Atlantic and Mediterranean subspecies

Table 5. - Introgression rates $(r)$ between domesticated strains and wild samples at diagnostic loci.

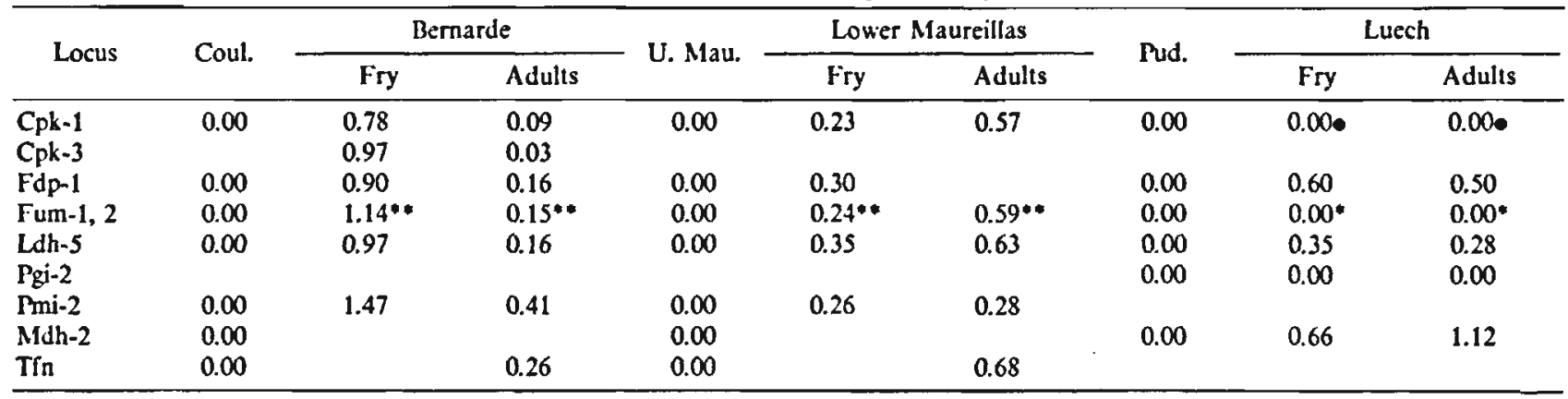

*: values based on the frequency of Fum-1, 2 (140). **: values based on the frequency of Fum-1, 2 (100). $\bullet:$ the exact values of $r$ are negative and reflect natural genetic differences between the unstocked and stocked populations; however, the absence of Cpk-1 (125) indicates that there is no hatchery contribution. Values greater than one could result from sampling errors, natural genetic differencies between unstocked and stocked populations, or allele frequency variations over generations in the hatchery strains.

and Ferguson (1984) observed a non-random assortment between $\Lambda$ at $-1,2$ and $M d h-2$ in both males and females. We failed to detect any evidence of linkage between these two loci. These results are not incompatible because both Aat-1 and 2 could be polymorphic and only one of them is likely to be linked to Mdh-2 (Taggart and Fergusson, 1984). We observed a non-random assortment between Mdh-2 and Mdh-3,4 which was not detected by Taggart and Fergusson has not resulted in reproductive isolation. This conclusion is consistent with results obtained from experimental crosses and electrophoretic studies of secondary contact between other salmonid species or subspecies. Reproductive success and normal survival rates have often been reported in $F 1$ experimenta] crosses between species or subspecies which are generally genetically more divergent than the Altnatic and Mediterranean brown trout subspecies (Chevassus, 

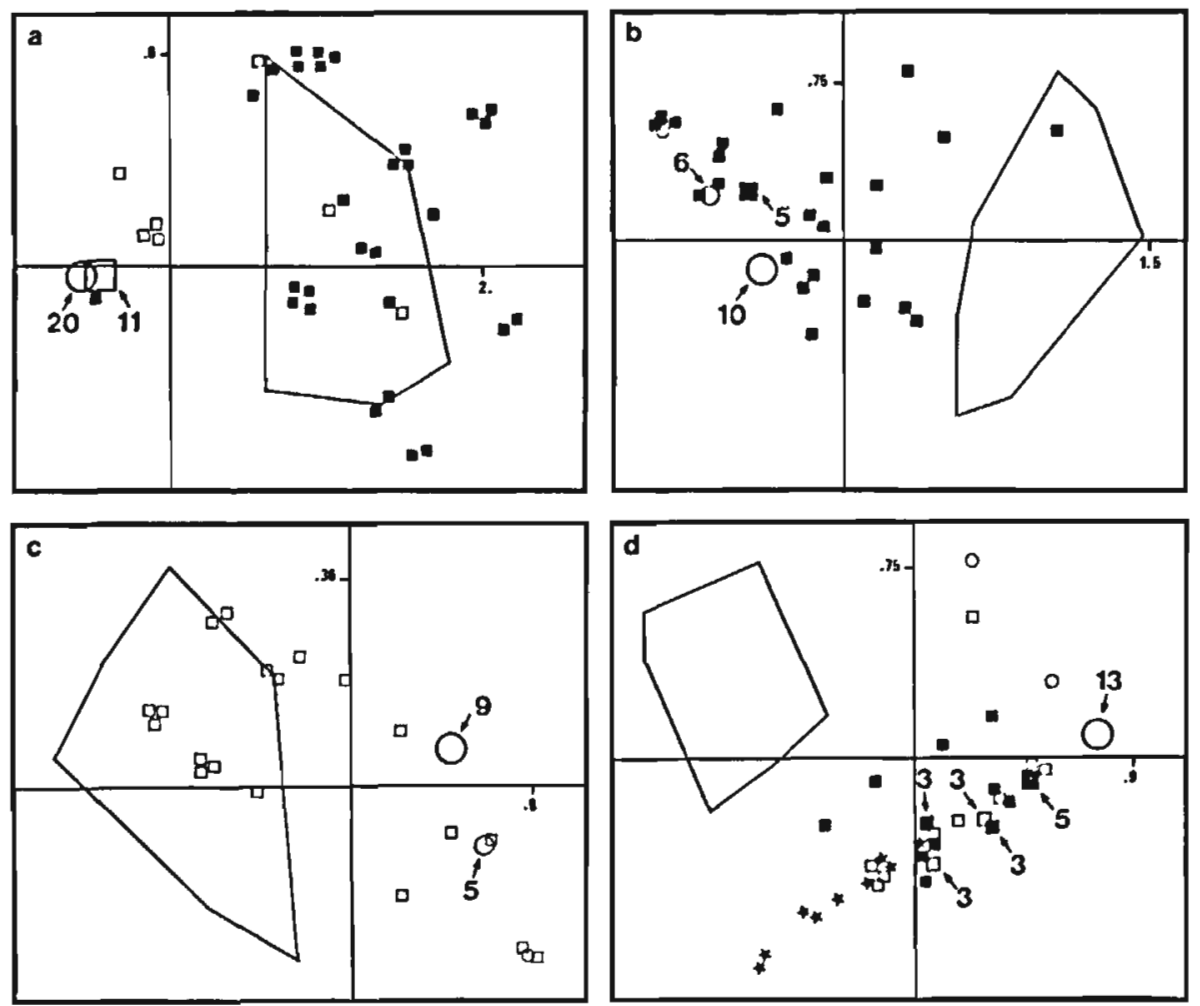

Figure 3. - Principal component analysis of allele frequencies in table 4 of wild and hatchery samples. Diagrams depict projections on the

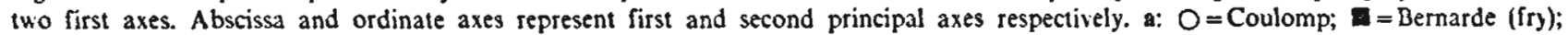
$\square=$ Bernarde (adults); $-=$ Roqucbillicre. b: $O=$ Upper Maureillas; $D=$ Lower Maureillas (Iry): $-=$ La Canourgue. c: $O=$ Upper Maureillas; $\square=$ Lower Maureillas (adults); $-=$ La Canourgue. d: $O=$ Pudissine; $\mathbf{U}=$ Luech (fry); $\square=$ Luech (adults); $-=$ La Canourgue; * = Lot (sample 7 on fig. 1). The wild individuals are shown. When several individuals have the same projection on the plane, their number is indicated. For the hatchery samples, only the smallest convex polygon bounding the sample space is shown.

Table 6. - Estimates of linkage desequilibrium (D; Hill, 1974) between diagnostic loci in the adult Bernarde (above diagonal) and adult Maureillas (below diagonal) samples.

\begin{tabular}{llllll}
\hline \multirow{2}{*}{ Locus } & \multicolumn{5}{c}{ Locus } \\
\cline { 2 - 6 } & Cpk-1, 2 & Fdp-1 & Ldh-5 & Pmi-2 & Tfn \\
\hline Cpk-3 & & $0.08^{* *}$ & $0.13^{* * *}$ & -0.03 & $0.13^{* * *}$ \\
Fdp-1 & & & $0.09^{* *}$ & 0.02 & $0.07^{*}$ \\
Ldh-5 & $0.08^{*}$ & & & $0.06^{*}$ & $0.12^{* *}$ \\
Pmi-2 & 0.03 & & 0.03 & & -0.04 \\
TIn & 0.04 & & $0.16^{* *}$ & 0.07 & \\
\hline
\end{tabular}

* $p<0.05 ; * *<0.01 ; * * *<0.001$.

1979; Blanc and Chevassus, 1979; Ferguson et al, 1985). Unfortunately, F2 crosses which could demonstrate conclusively a reproductive barrier between these taxa have not been performed. Electrophoretic analysis of introgressed natural salmonids populations has failed to detect any reproductive barrier for genetic distances much higher than 0.10 (Busack and Gall, 1981; Campton and Utter, 1985; Ferguson $e t$ al., 1985; Gyllensten et al., 1985). Leary et al. (1983) reported naturally occurring stcrile, all malc, first generation hybrids between brook trout and bull trout (Nei's standard distance $=0.37$ ). Genctic incompatibility apparently occurs at higher values (Ferguson et al., 1985). A positive relationship between genetic distance and degree of genetic incompatibility has been also observed in sunfish (Whitt, 1981; Philipp ct al., 1983).

According to these findings, it is unlikely that the gametic phase desequilibrium and deviations from IIardy-Weinberg expectations observed in adult lower Maureillas fish indicate a reproductive barrier. Rather, they most likely result from the recent admixture of domesticated and native fish ( $f$ ig. $3 b$ ). In the age $0^{+}$fish from lower Maurcillas, the genotype frequencies conformed to Hardy-Weinberg expectations and there was no evidence of gametic phase desequilibrium. This suggests that the stocking performed during the year largely failed.

No or little stocking effects were observed in the Luech site. Our results from the lower Maurcillas and Bernarde sites and the reports previously mentioned have shown clearly that transplantation and stocking can modify significantly the genetic structure of native 
populations for a wide range of salmonid species and subspecies. Genetic factors alone, therefore, are unlikely to account for the situation observed in the Luech river. Environmental factors are the most likely explanations. Such factors are numerous and difficult to identify. In the Bernarde site, the lack of wild fry suggested that the release site was not suitable for a definitive implantation of the alevins.

We cannot exclude the possibility that introgression may improve the fitness of local populations in some circumstances. The effects of stocking on the biology of the wild stocks can only be deduced from field studies. Therefore, it is unjustifiable to condemn current stocking practices simply because electrophoretic studies show evidence of introgression. From our present knowledge, we should define by electrophoresis a sulficiently large number of native populations and protect them in situ from any human intervention. These populations could be used in restoration programs if this is considered desirable in the future.

\section{Acknowledgements}

This work was supported by CSP. (Conseil supérieur de la pêche) grants (réf. CSP: 85/329). The authors whish to thank the two anonymous referees for their hejpful suggestions and B. Reynicr (CSP, délégation régionale de Montpellier) for supplying samples.

\section{REFERENCES}

Allendorf F. W., F. M. Utter, 1979. Population genetics. In: Fish physiology, Vol. 8, IV. S. Hoar, D. J. Randall, J. R. Brett Eds., Academic Press, New York, 1-53.

Blanc J. M., B. Chevassus, 1979. Interspecilic hybridization in salmonid fish. I. Hactching and survival up to the 15 th day after hatching in F1 generation hybrids. Aquaculture, 18, 21-34.

Campton D. E., 1987. Natural hybridization and introgression in fishes: Methods of detection and genetic interpretations. In: Population genetics and fishery management, N. Ryman, F. W. Utter Eds., University of Washington Press, Seattle and London, 161-192.

Campton D. E., F. M. Utter, 1985. Natural hybridization between stcelhead trout (Salmo gairdneri) and coastal cutthroat (Salmo clarki clarki) in two Puget Sound Streams. Can. J. Fish. Aquat. Sci., 42, 110-119.

Chevassus B., 1979. Hybridization in salmonids: results and perspectives. Aquaculture, 17, 113-128.

Fergusson M. M., R. G. Danzmann, F. W. Allendorf, 1985. Absence of developmental incompatibility in hybrids between rainbow trout and subspecies of cutthroat trout. Bioch. Genet., 23, 557-570.

Glass B., C. C. Li, 1953. The dynamics of racial admixture: an analysis based on the American negroes. Am. J. Hum. Genet., 7, 368-385.

Guyomard R., 1986. Gene segregation in gynogenetic brown trout (Salmo trutra L.): systematically high frequencies of post-reduction. Genet. Sel. Evol., 18, 385-392.

Guyomard R., F., Krieg, 1983. Electrophorctic variations in six populations of brown trout (Salmo trutta L.). Can. J. Genet. Cytol., 25, 403-413.

Guyomard R., F. Krieg, 1986. Mise en évidence d'un flux génique cntre populations naturelles de truite fario et souche de repeuplement dans deux rivières corses. Bull. Fr. Pêche Pisci., 303, 125-133.
Gyllensten U., R. F. Leary, F. W. Allendorf, A. C. Wilson, 1985. Introgression between two cutthroat trout subspecies with substantial karyotypic, nuclear and mitochondrial genomic divergence. Genetic, 111, 905-915.

Hill W. G., 1974. Estimation of linkage desequilibrium in randomly mating populations. Heredity, 33, 229-239.

Krieg F., R. Guyomard, 1985. Population genetics of French brown trout (Salmo trutta L.): large geographical differentiation of wild populations and high similarity of domesticated stocks. Genet. Sel. Erol., 17, 369-376.

Leary R. F., F. W. Allendorf, K. L. Knudsen, 1983. Consistently high meristic counts in nalural hybrids between brook trout and bull trout. Syst. Zool, 32, 369-376.

Leary R. F., F. W. Allendorf, S. R. Phelps, K. Knudsen, 1987. Genetic divergence and identification of seven cutthroat trout subspecies and rainbow trout. Trans. Am. Fish. Soc., 116, 580-587.

Lebart L., A. Morineau, K. M. Worwick, 1984. Multivariate descriptive analysis. John Wiley and Sons, New York, $231 \mathrm{p}$.

Loudenslager E. J., G. A. E. Gall, 1980. Geographic patterns of protein variations and subspeciation in cutthroat (Salmo clarki). Sy'st. Zool., 28, 27-42.

May B., J. E. Wright, M. Stoneking, 1979. Joint segregation loci in salmonidae: Results from experiments with Salvelinus and reviews of the literature on other species. $J$. Fish. Res. Board Can., 36, 1114-1128.

Mather K., 1951. The measurement of linkage in heredity. Methuen, London, $149 \mathrm{p}$.

Nei M., 1975. Molecular population genetics and evolution. North Holland, Amsterdam and New York, 228 p.

Philipp D. P., H. R. Parker, G. S. Whitt, 1983. Evolution of gene regulation: Isozymic analysis of patterns of gene expression during hybrid fish development. In: Isozymes: Current topics in biological and medical research, M. C. 
Ratazzi, J. G. Scandalios, G. S. Whitt Eds., Alan R. Liss Inc., New York, 193-237.

Schwartz F. J., 1972. World literature to fish hybrids, with an analysis by family, species and hybrid. Publications of the Gulf Coast Research Laboratory Museum, No. 3, Gulf Research Laboratory, Ocean Springs, Massachusetts, $328 \mathrm{p}$.

Smith R. C., 1981. Biochemical genetics and meristic analysis of populations of little kern river basin golden trout. $P h$. D. Thesis, University of Washington, Seattle, $65 \mathrm{p}$.
Stoneking J. B., D. J. Wagner, A. C. Hildebrand, 1981. Genetic evidence suggesting subspecific differences between northern and southern populations of brook trout (Salvelinus fontinalis). Copeia, 810-819.

Taggart J. B., A. Ferguson, 1984. Allozyme variation in the brown trout (Salmo trutta L.): single locus and joint segregation inheritance studies. Heredity, 53, 339-359.

Whitt G. S., 1981. Developmental genetics of fishes: Isozymic analyses of differential gene expression. Am. Zool., 21, 549-572. 